\title{
molecules
}

ISSN 1420-3049

www.mdpi.com/journal/molecules

Article

\section{Chemical Composition and Biological Activities of the Essential Oils from Duguetia lanceolata St. Hil. Barks}

Orlando V. Sousa ${ }^{1}{ }^{1}$, Glauciemar Del-Vechio-Vieira ${ }^{1}$, Maria S. Alves ${ }^{1}$, Aílson A. L. Araújo ${ }^{1}$, Míriam A. O. Pinto ${ }^{1}$, Maria P. H. Amaral ${ }^{1}$, Mírian P. Rodarte ${ }^{1}$ and Maria A. C. Kaplan ${ }^{2}$

1 Department of Pharmaceutical Sciences, Faculty of Pharmacy, Federal University of Juiz de Fora, São Pedro, Juiz de Fora, Minas Gerais, 36036-330, Brazil;

E-Mails: glauciemar@gmail.com (G.D.-V.-V.); alves_ms2005@yahoo.com.br (M.S.A.); ailson.luz@ufjf.edu.br (A.A.L.A.); miriamaop@yahoo.com.br (M.A.O.P.); penhaufj@@yahoo.com.br (M.P.H.A.); mirianpereira.rodarte@ufjf.edu.br (M.P.R.)

2 Department of Natural Products Research, Center of Health Sciences, Federal University of Rio de Janeiro, Ilha do Fundão, Rio de Janeiro, Rio de Janeiro, 21941-590, Brazil; E-Mail: makaplan@uol.com.br

* Author to whom correspondence should be addressed; E-Mail: orlando.sousa@ufjf.edu.br; Tel.: +55-32-2102-3808; Fax: +55-32-2102-3812.

Received: 13 June 2012; in revised form: 15 August 2012 / Accepted: 4 September 2012 / Published: 13 September 2012

\begin{abstract}
Essential oils of Duguetia lanceolata barks, obtained at 2 (T2) and 4 h (T4), were identified by gas chromatography and gas chromatography/mass spectrometry. $\beta$-Elemene (12.7 and 14.9\%), caryophyllene oxide (12.4 and 10.7\%) and $\beta$-selinene (8.4 and $10.4 \%$ ) were the most abundant components in T2 and T4, respectively. The essential oils inhibited the growth of Staphylococcus aureus, Streptococcus pyogenes, Escherichia coli and Candida albicans. The essential oils were cytotoxic against brine shrimp. The extraction time influenced the chemical composition and biological activities of essential oils obtained from the barks of $D$. lanceolata.
\end{abstract}

Keywords: Duguetia lanceolata; Annonaceae; essential oil; antimicrobial activity; brine shrimp lethality bioassay 


\section{Introduction}

Plant and their essential oils are potentially useful sources of bioactive compounds. Some studies have described the biological activities of essential oils against many different types of agents, including important organisms of clinical relevance [1,2]. Among the main constituents found in the essential oils, the mono- and sesquiterpenes, phenylpropanoids and benzenoid oxygenated derivatives are highlighted. These substances are responsible for the fragrance and for different biological properties [3].

The genus Duguetia, Annonaceae family, is composed by around 100 species and possesses as chemical markers alkaloids and acetogenins [4,5]. However, essential oils have also been identified in different species of this genus [6]. Considering the biological activities, essential oils from Duguetia gardneriana Mart. and Duguetia moricandiana Mart. showed antimicrobial activity [7], while such constituents obtained from Duguetia glabriuscula R. E. Fries (R.E. Fries) were active against Artemia salina [8].

Duguetia lanceolata St. Hil., popularly known as pindaíba, beribá or pinhão, is a pereninnial species distributed in several States of Brazil [5]. This species is native in this country and found in the Cerrado and Atlantic Forest, especially in Minas Gerais, Mato Grosso and São Paulo States. In folk medicine, this plant has been used as an anti-inflammatory, cicatrizing and antimicrobial agent [9]. Pharmacological studies have demonstrated that $D$. lanceolata presented antinociceptive, anti-inflammatory and antiplasmodial activities [9-11].

Considering that we did not find any previously published original articles about essential oils of D. lanceolata and in order to provide the scientific basis for the medicinal use of this species, the present study was designed to evaluate the chemical composition and the biological activities of essential oils from barks of this plant. The influence of the extraction time in the obtainment of essential oils in these two propositions for investigation was also analyzed.

\section{Results and Discussion}

This is the first time that the chemical composition of $D$. lanceolata is described in the literature. According to the Table 1, seventy-two compounds were identified in the essential oils from D. lanceolata barks, classified as terpenes (mono- and sesquiterpenes) and hydrocarbons. This total number of detected components (72) was found in the first two hours (T2) and fifty-one in the other four hours (T4). Among those identified in T2, twenty-five were monoterpenes and forty-seven were sesquiterpenes. Considering the time T4, nine were monoterpenes and forty-two were sesquiterpenes. The relation between the monoterpenes and the extraction time was $\mathrm{T} 2=2.8 \times \mathrm{T} 4$, while for the sesquiterpenes was T2 $=1.1 \times \mathrm{T} 4$, demonstrating a relevant loss of monoterpenes.

trans-Pinocarveol (1.4 and $0.4 \%)$ and myrtenol $(0.8$ and $0.5 \%)$ were the most abundant monoterpenes observed in both times $\mathrm{T} 2$ and $\mathrm{T} 4$, with reduction of $71.4 \%$ and $37.5 \%$, respectively (Table 1). Considering the twenty-five monoterpenes identified in T2, sixteen were absent in T4. Probably, the volatility and the time of hydrodistillation $(4 \mathrm{~h})$ caused a greater loss of this chemical class of secondary metabolite. Thus, these factors could influence the biological activities. 
Sesquiterpenoids represented the highest number of constituents detected in the essential oil of D. lanceolata barks. $\beta$-Elemene (12.7 and 14.9\%), caryophyllene oxide (12.4 and $10.7 \%$ ), $\beta$-selinene (8.4 and 10.4\%), $\beta$-eudesmol (6.8 and 7.9\%), humulene epoxide II (7.4 and 6.8\%), ledol (3.9 and 3.9\%), viridiflorol (3.5 and 3.0\%), khusinol (3.6 and 5.0\%), $\beta$-senensal (3.2 and 5.4) and patchouli alcohol (3.2 and 3.8\%) were the most concentrated components in $\mathrm{T} 2$ and $\mathrm{T} 4$, respectively (Table 1). It is possible that these constituents can represent important chemical markers to the essential oil of this species.

Table 1. Constituents of the essential oils from $D$. lanceolata barks.

\begin{tabular}{|c|c|c|c|c|}
\hline \multirow{2}{*}{ Compound } & \multirow{2}{*}{$\mathbf{R I}^{\mathbf{a}}$} & \multicolumn{2}{|c|}{ Concentration (\%) } & \multirow{2}{*}{ Identification } \\
\hline & & $2 \mathrm{~h}$ & $4 \mathrm{~h}$ & \\
\hline$\alpha$-Pinene & 937 & 0.1 & - & RI, GC-MS \\
\hline Verbenene & 984 & 0.1 & - & RI, GC-MS \\
\hline$\beta$-Pinene & 1018 & 0.1 & - & RI, GC-MS \\
\hline$p$-Cymene & 1075 & 0.7 & - & RI, GC-MS \\
\hline Limonene & 1081 & 0.4 & - & RI, GC-MS \\
\hline$p$-Cymenene & 1153 & 0.2 & 0.1 & RI, GC-MS \\
\hline Dehydrosabina ketone & 1194 & 0.1 & - & RI, GC-MS \\
\hline$\alpha$-Campholenal & 1202 & 0.1 & - & RI, GC-MS \\
\hline trans-Pinocarveol & 1215 & 1.4 & 0.4 & RI, GC-MS \\
\hline cis-Verbenol & 1221 & 0.4 & - & RI, GC-MS \\
\hline trans-p-Menth-2-en-1-ol & 1225 & 0.1 & - & RI, GC-MS \\
\hline Camphor & 1235 & 0.1 & - & RI, GC-MS \\
\hline Menthofuran & 1240 & 0.1 & - & RI, GC-MS \\
\hline$p$-Mentha-1,5-dien-8-ol & 1244 & 0.2 & 0.2 & RI, GC-MS \\
\hline Umbellulone & 1251 & 0.1 & - & RI, GC-MS \\
\hline Terpin-4-ol & 1256 & 0.4 & 0.1 & RI, GC-MS \\
\hline p-Cymen-8-ol & 1265 & 0.2 & - & RI, GC-MS \\
\hline$\alpha$-Terpineol & 1270 & 0.1 & 0.1 & RI, GC-MS \\
\hline Myrtenol & 1278 & 0.8 & 0.5 & RI, GC-MS \\
\hline Verbenone & 1292 & 0.3 & 0.1 & RI, GC-MS \\
\hline trans-Carveol & 1302 & 0.2 & 0.1 & RI, GC-MS \\
\hline Citronellol & 1317 & 0.4 & - & RI, GC-MS \\
\hline Cumin aldehyde & 1323 & 0.1 & - & RI, GC-MS \\
\hline Carvone & 1328 & 0.1 & - & RI, GC-MS \\
\hline Bornyl acetate & 1374 & 0.7 & 0.4 & RI, GC-MS \\
\hline$\alpha$-Cubebene & 1440 & 0.1 & 0.1 & RI, GC-MS \\
\hline Cyclosativene & 1457 & 1.4 & 1.4 & RI, GC-MS \\
\hline$\alpha$-Copaene & 1466 & 0.3 & 0.3 & RI, GC-MS \\
\hline$\beta$-Elemene & 1491 & 12.7 & 14.9 & RI, GC-MS \\
\hline (Z)-Caryophyllene & 1497 & 0.2 & 0.1 & RI, GC-MS \\
\hline$\alpha$-Gurjunene & 1502 & 0.2 & - & RI, GC-MS \\
\hline (allo)-Aromadendrene & 1531 & 0.1 & 0.1 & RI, GC-MS \\
\hline$\beta$-Chamigrene & 1539 & 0.1 & 0.1 & RI, GC-MS \\
\hline$\gamma$-Muurolene & 1553 & 0.3 & - & RI, GC-MS \\
\hline$\gamma$-Curcumene & 1571 & 1.1 & 1.1 & RI, GC-MS \\
\hline$\beta$-Selinene & 1587 & 8.4 & 10.4 & RI, GC-MS \\
\hline
\end{tabular}


Table 1. Cont.

\begin{tabular}{|c|c|c|c|c|}
\hline \multirow{2}{*}{ Compound } & \multirow{2}{*}{$\mathbf{R I}^{\mathrm{a}}$} & \multicolumn{2}{|c|}{ Concentration (\%) } & \multirow{2}{*}{ Identification } \\
\hline & & $2 \mathrm{~h}$ & $4 \mathrm{~h}$ & \\
\hline Valencene & 1589 & 0.3 & 0.3 & RI, GC-MS \\
\hline$\alpha$-Selinene & 1592 & 0.6 & 0.6 & RI, GC-MS \\
\hline Cuparene & 1596 & 0.4 & 0.4 & RI, GC-MS \\
\hline Germacrene A & 1604 & 0.8 & 0.6 & RI, GC-MS \\
\hline$\alpha$-Bulnesene & 1608 & 0.6 & 0.6 & RI, GC-MS \\
\hline$\gamma$-Cadinene & 1611 & 0.5 & 0.5 & RI, GC-MS \\
\hline$\delta$-Cadinene & 1623 & 1.2 & 1.4 & RI, GC-MS \\
\hline (Z)-Nerolidol & 1630 & 1.2 & 0.8 & RI, GC-MS \\
\hline 8,14-Cedranoxide & 1639 & 0.5 & 0.3 & RI, GC-MS \\
\hline$\alpha$-Calacorene & 1642 & 0.9 & 1.2 & RI, GC-MS \\
\hline Occidentalol & 1651 & 1.4 & 1.3 & RI, GC-MS \\
\hline Elemol & 1655 & 0.3 & - & RI, GC-MS \\
\hline Ledol & 1667 & 3.9 & 3.9 & RI, GC-MS \\
\hline Longipinanol & 1670 & 2.4 & 0.3 & RI, GC-MS \\
\hline Caryophyllene oxide & 1690 & 12.4 & 10.7 & RI, GC-MS \\
\hline Gleenol & 1697 & 0.4 & - & RI, GC-MS \\
\hline Davanone & 1700 & 0.5 & 1.0 & RI, GC-MS \\
\hline Viridiflorol & 1707 & 3.5 & 3.0 & RI, GC-MS \\
\hline Humulene epoxide II & 1716 & 7.4 & 6.8 & RI, GC-MS \\
\hline Hinesol & 1725 & 0.2 & 0.8 & RI, GC-MS \\
\hline Epi- $\alpha$-Cadinol & 1733 & 3.2 & 3.0 & RI, GC-MS \\
\hline Cubenol & 1735 & 0.6 & - & RI, GC-MS \\
\hline$\alpha$-Muurolol & 1747 & 1.0 & 0.9 & RI, GC-MS \\
\hline$\beta$-Eudesmol & 1759 & 6.8 & 7.9 & RI, GC-MS \\
\hline Patchouli alcohol & 1763 & 3.2 & 3.8 & RI, GC-MS \\
\hline Lyral & 1773 & 1.2 & 1.2 & RI, GC-MS \\
\hline Cadalene & 1780 & 1.7 & 2.2 & RI, GC-MS \\
\hline Khusinol & 1788 & 3.6 & 5.0 & RI, GC-MS \\
\hline (E)-Asarone & 1810 & 0.8 & 1.1 & RI, GC-MS \\
\hline cis-14-Muurolol-5-en-4-one & 1817 & 0.5 & 0.8 & RI, GC-MS \\
\hline Germacrone & 1833 & 0.8 & 0.5 & RI, GC-MS \\
\hline$\beta$-Sinensal & 1862 & 3.2 & 5.4 & RI, GC-MS \\
\hline Caryophyllene acetate & 1867 & 0.8 & 2.0 & RI, GC-MS \\
\hline n-Heptadecane & 1915 & 0.2 & 0.2 & RI, GC-MS \\
\hline$n$-Nonadecane & 2022 & 0.1 & 0.1 & RI, GC-MS \\
\hline$n$-Eicosane & 2129 & 0.1 & 0.2 & RI, GC-MS \\
\hline Total & - & 99.6 & 99.3 & - \\
\hline Monoterpene hydrocarbons & - & 1.6 & 0.1 & - \\
\hline Oxygenated monoterpenes & - & 5.9 & 1.8 & - \\
\hline Sesquiterpene hydrocarbons & - & 31.9 & 36.3 & - \\
\hline Oxygenated sesquiterpenes & - & 59.8 & 60.5 & - \\
\hline Hydrocarbons & - & 0.4 & 0.5 & - \\
\hline Unidentified & - & 0.4 & 0.7 & - \\
\hline Yield (\%) & - & 0.5 & 0.5 & - \\
\hline
\end{tabular}

${ }^{\mathrm{a}}$ Retention index on HP-5 MS column. 
The increased contents of some sesquiterpenes in T4 can be due to the loss of monoterpenes during the extraction procedure. It was also observed that the constituents with the highest content in T2 remained high in T4. Thus, the concentrations of constituents identified were 99.6 and $99.3 \%$ in T2 and $\mathrm{T} 4$, respectively (Table 1).

The absence of five sesquiterpenes in T4 may be attributed to the low concentration of these constituents in $\mathrm{T} 2$, which ranged from $0.2 \%$ to $0.6 \%$ and to the quality of the oil extracted from barks of different parts of the stem. Therefore, the influence of the time of hydrodistillation, as described with the monoterpenes, is an important factor to be observed during the extraction of essential oils. Moreover, the water, acidity and temperature involved in the hydrodistillation procedure may also cause hydrolysis, rearrangements, isomerizations, racemizations and oxidations, altering the molecular structures $[12,13]$.

Although differences are visualized in the chemical composition of essential oils of the genus Duguetia, some constituents are conserved in several species. $\alpha$-Pinene, $\beta$-pinene, $p$-cymene, limonene, $\gamma$-muurolene, valencene, $\gamma$-cadinene and $\delta$-cadinene found in $D$. lanceolata have also been observed in D. asterotricha [14], while (allo)-aromadendrene, $\delta$-cadinene and viridiflorol were identified in D. glabriuscula [8]. The main compounds found in D. eximia were $\alpha$-eudesmol and spathulenol [6]. Considering an example of the difference observed in the parts of the same species, the leaf and fine stems oil of $D$. flagellaris was dominated by spathulenol and $\alpha$-muurolol, while the bark oil was mainly constituted by germacrene $\mathrm{D}$, cyperene, $\alpha$-muurolol, humulene epoxide II and spathulenol [6]. The major components identified in the oil of D. pycnastera were spathulenol, allo-aromadendrene, germacrene D and elemol. The oil of D. riparia contained spathulenol, caryophyllene oxide and $\alpha$-pinene as their main compounds [6]. The oil of D. trunciflora was dominated by $\alpha$-pinene, bicyclogermacrene, bulnesol, spathulenol, guaiol, globulol and humulene epoxide II; the bark oil was dominated by $\beta$-phellandrene, guaiol and $\alpha$-cadinol [6]. Germacrene D, viridiflorene, $\beta$-pinene, $\alpha$-pinene and $\beta$-caryophyllene were found to be the major individual constituents of D. gardneriana oil [7]. The leaf oil of D. moricandiana was dominated by germacrene D, $\alpha$-pinene, viridiflorene, $\beta$-pinene and $\beta$-caryophyllene [7]. Possibly, the conservation of these constituents in species of the genus Duguetia may have chemotaxonomic significance to maintain similar morphologic and biochemistry characteristics, which will determine the biosynthesis of their secondary metabolism.

Considering the biological properties, the antimicrobial activity of the essential oils from barks of D. lanceolata was tested against representative microbial groups using ATCC reference strains. Using disks impregnated with 5, 10 and $25 \mathrm{mg}$ of essential oils obtained in the times T2 and T4, an inhibition zone of the bacteria growth was observed with Gram-positive Staphylococcus aureus and Streptococcus pyogenes and Gram-negative E. coli, but not with Pseudomonas aeruginosa (Table 2). The essential oil obtained in the time T2 was more active against the fungi $C$. albicans. Despite being active against Gram-positive bacteria, the activity of the essential oils demonstrated against $S$. aureus was smaller when compared as chloramphenicol used as an antibiotic control. The MIC data confirmed the activity against the tested microorganisms, as shown in Table 3. The MIC values ranged from 20 to $125 \mu \mathrm{g} / \mathrm{mL}$ and 2 to $8 \mu \mathrm{g} / \mathrm{mL}$ for oils and chloramphenicol, respectively, and was $15 \mu \mathrm{g} / \mathrm{mL}$ for nystatin (Table 3 ). 
Table 2. Antimicrobial activity of the essential oils from Duguetia lanceolata barks.

\begin{tabular}{|c|c|c|c|c|c|c|c|}
\hline \multirow{3}{*}{ Microorganism } & \multicolumn{7}{|c|}{ Inhibition zone (mm) } \\
\hline & \multicolumn{3}{|c|}{ Essential oil T2 (mg) } & \multicolumn{3}{|c|}{ Essential oil T4 (mg) } & \multirow{2}{*}{ Contro } \\
\hline & 5 & 10 & 25 & 5 & 10 & 25 & \\
\hline Staphylococcus aureus & 10.5 & 10.5 & 15.0 & 9.5 & 10.0 & 12.5 & 26.0 \\
\hline Streptococcus pyogenes & 11.0 & 12.5 & 18.0 & 10.0 & 11.0 & 14.0 & 28.0 \\
\hline Escherichia coli & - & - & 10.0 & - & - & - & 25.0 \\
\hline Pseudomonas aeruginosa & - & - & - & - & - & - & 21.0 \\
\hline Candida albicans & - & 10 & 14 & - & - & 12 & 22.0 \\
\hline
\end{tabular}

Experiments were done in duplicate and results were mean values.

Table 3. Minimal inhibitory concentration (MIC) of the essential oils from Duguetia lanceolata barks.

\begin{tabular}{lccc}
\hline \multirow{2}{*}{ Microorganism } & \multicolumn{3}{c}{ MIC $(\boldsymbol{\mu g} / \mathbf{m L})$} \\
\cline { 2 - 4 } & Essential oil T2 & Essential oil T4 & Control \\
\hline Staphylococcus aureus & 60 & 125 & 2 \\
Streptococcus pyogenes & 20 & 40 & 4 \\
Escherichia coli & - & - & 8 \\
Pseudomonas aeruginosa & - & - & - \\
Candida albicans & 60 & 100 & 15 \\
\hline
\end{tabular}

Experiments were done in duplicate and results were mean values.

Few works on the antibacterial activity of essential oils extracted from plants of the genus Duguetia are found in literature. One of these studies showed that the essential oil of D. gardneriana had activity against $S$. aureus and Candida guilliermondii, while the essential oil of $D$. moricandiana was more active against $S$. aureus and Candida albicans [7]. Several constituents of the oils of these species are also present in the essential oils from barks of $D$. lanceolata. It is possible that the antimicrobial activity demonstrated by the oil extracted from $D$. lanceolata could be attributed to these components.

It has been suggested that the antimicrobial activity of essential oils is attributable to the presence of compounds such as alcohols, aldehydes, alkenes, esters and ethers [15], some found in the oil of $D$. lanceolata. For instance, the essential oil of $D$. lanceolata contains substances as $\delta$-cadinene, $\alpha$-terpineol and elemol, found in several vegetal species, which have demonstrated bacteriostatic and antiseptic activities [16]. $p$-Cymene, $\beta$-pinene, humulene epoxide II and caryophyllene oxide identified in Solanum erianthum and Solanum macranthum also have inhibited the growth of microorganisms [17]. In addition, caryophyllene oxide, $\alpha$-terpineol and limonene displayed antifungal activity against onychomycosis, Candida albicans and Cryptococcus neoformans [18,19]. However, independent on the involved species [20], it is important to mention that the antimicrobial activity could be due the synergistic action of different compounds observed in this plant.

The essential oils from barks of $D$. lanceolata obtained in the times T2 and T4 were poisonous against Artemia salina with following LC $_{50}$ values: $49.0(30.2-79.2) \mu \mathrm{g} / \mathrm{mL}$ and $60.7(37.1-99.3) \mu \mathrm{g} / \mathrm{mL}$, respectively (Table 4). According to the data presented in the Table 4, the results showed that the essential oil T2 was around 9 times and essential oil T4 was around seven times more poisonous than thymol $\left(\mathrm{LC}_{50}=457.9 \mu \mathrm{g} / \mathrm{mL}\right)$, the reference substance. 
Table 4. Toxicity of the essential oils from Duguetia lanceolata barks.

\begin{tabular}{lcc}
\hline Tested product & $\mathbf{L C}_{\mathbf{5 0}}(\boldsymbol{\mu \mathbf { g }} / \mathbf{m L})$ & Confidence interval $\mathbf{( 9 5 \% )}$ \\
\hline Essential oil T2 & 49.0 & $30.2-79.2$ \\
Essential oil T4 & 60.7 & $37.1-99.3$ \\
Thymol $^{\text {a }}$ & 457.9 & $318.6-658.1$ \\
\hline
\end{tabular}

${ }^{\mathrm{a}}$ Reference drug.

Species of the genus Duguetia have been studied by using the A. salina bioassay, a simple model applied to the toxicity investigation [21]. For example, the essential oil from leaves of D. glabriuscula (allo-aromadendrene and bicyclogermacrene-main constituents) presented a potent toxicity on A. salina with $\mathrm{LC}_{50} 1.6 \mu \mathrm{g} / \mathrm{mL}$ [8]. Despite the concentration of $0.1 \%$ in oils of D. lanceolata, allo-aromadendrene can contribute with the toxicity in this assay because this compound produced $\mathrm{LC}_{50} 7.8 \mu \mathrm{g} / \mathrm{mL}$, demonstrating to be one of the active substances responsible for this event [8]. In addition, hexanic and methanolic extracts of D. glabriuscula were toxic against $A$. salina [8].

\section{Experimental}

\subsection{Plant Material and Preparation Procedure}

Duguetia lanceolata St. Hil. was collected in the city of Juiz de Fora, Minas Gerais State, Southeast region of Brazil. A voucher specimen identified by Dr. Fátima Regina Gonçalves Salimena was deposited in the Herbarium of the Departamento de Botânica of the Universidade Federal de Juiz de Fora (CESJ number 29750). The barks were removed from the discarded branches after pruning, submitted to drying at room temperature and triturated for the extraction of the essential oil.

\subsection{Extraction of the Essential Oils}

Essential oils were obtained from $100 \mathrm{~g}$ D. lanceolata barks with $5 \%$ of humidity and $7 \%$ of total ashes by hydrodistillation using a Clevenger apparatus for $2 \mathrm{~h} \mathrm{(T2)}$ and $4 \mathrm{~h}$ (T4) at $100{ }^{\circ} \mathrm{C}$. After, the essential oils were dried with anhydrous sodium sulphate and stored under refrigeration at $-18{ }^{\circ} \mathrm{C}$ for analysis (the yield was $0.5 \% \mathrm{v} / \mathrm{w}$ ).

\subsection{Gas Chromatographic Analysis}

Capillary gas chromatography was performed using a Hewlett-Packard 6890 gas chromatograph under the following conditions: fused silica capillary column HP-5 (5\% diphenyl and 95\% dimethylpolysyloxane, $60 \mathrm{~m} \times 0.25 \mathrm{~mm}, 0.25 \mu \mathrm{m}$ film thickness $)$; helium as carrier gas $(1 \mathrm{~mL} / \mathrm{min})$; and temperature programming from 70 to $290{ }^{\circ} \mathrm{C}\left(2{ }^{\circ} \mathrm{C} / \mathrm{min}\right)$; injector temperature $270{ }^{\circ} \mathrm{C}$ and detector temperature $300{ }^{\circ} \mathrm{C}$.

\subsection{Gas Chromatography/Mass Spectrometry Analysis (GC/MS)}

The GC/MS analysis of the essential oils was performed on a Hewlett Packard series 6890 gas chromatograph coupled to HP5972 mass spectrometer under the following analytical conditions: ZB-5MS column $(30 \mathrm{~m} \times 0.25 \mathrm{~mm} \times 0.25 \mu \mathrm{m}$ film thickness $)$; helium $(1 \mathrm{~mL} / \mathrm{min})$; programmed 
temperature $60-240{ }^{\circ} \mathrm{C}\left(3{ }^{\circ} \mathrm{C} / \mathrm{min}\right)$; injector temperature $\left(260{ }^{\circ} \mathrm{C}\right)$ and interface $\left(200{ }^{\circ} \mathrm{C}\right)$; ionization energy, $70 \mathrm{eV}$; scan range, 30-300 amu; scan time, $1 \mathrm{~s}$. Compound identification was based on the comparison of retention index (determined relatively to the retention times of a $n$-alkanes series), mass spectra and the NIST spectrometer data bank, as well as comparison with literature data [22,23].

\subsection{Representative Microbial Groups by ATCC Reference Strains}

The essential oils of $D$. lanceolata were tested against a panel of representative microorganisms including Staphylococcus aureus (ATCC 6538), Streptococcus pyogenes (ATCC 19615), Escherichia coli (ATCC 8739), Pseudomonas aeruginosa (ATCC 15442) and Candida albicans (ATCC 10231) which belong to the American Type Culture Collection (ATCC).

\subsection{Screening for Antimicrobial Activity}

The antimicrobial activity was tested through agar diffusion method [24]. Mueller Hinton Agar was used as the standard test medium for bacteria, with exception of Streptococcus pyogenes (in this case, the Mueller Hinton Agar was supplemented with Sheep Blood at 8\%), and Sabouraud Agar for yeast. Overnight broth cultures were prepared, adjusted in peptone-physiological salt solution (1 g peptone and $8.5 \mathrm{~g} / \mathrm{L} \mathrm{NaCl}$ ) to yield approximately $10^{6}$ bacteria $/ \mathrm{mL}$ and $10^{5}$ conidia $/ \mathrm{mL}$. The agar plates were prepared in $90 \mathrm{~mm}$ Petri dishes with $22 \mathrm{~mL}$ of agar medium giving a final depth of $4 \mathrm{~mm}$. Sterile cellulose discs, diameter $6 \mathrm{~mm}$, were placed on the inoculated agar surfaces with $100 \mu \mathrm{L}$ of diluted oil in hexane. Each $100 \mu \mathrm{L}$ had 5, 10 or $25 \mathrm{mg}$ of essential oil. Hexane $(100 \mu \mathrm{L})$ was used as negative control. All plates were aerobically incubated at $35 \pm 2{ }^{\circ} \mathrm{C}$ for $18-24 \mathrm{~h}$ (bacteria) and at $22{ }^{\circ} \mathrm{C}$ for $48 \mathrm{~h}$ (yeast). The antimicrobial activity was estimated by measuring the radius of the inhibition zone ( $\mathrm{mm}$ ). Each test was performed in duplicate and the results were shown as means. $20 \mu \mathrm{L}$ of chloramphenicol $(1 \mathrm{mg} / \mathrm{mL})$ for bacteria and $20 \mu \mathrm{L}$ of nystatin $(1 \mathrm{mg} / \mathrm{mL})$ for the yeast were used as positive controls.

\subsection{Determination of the Minimum Inhibitory Concentration}

The broth microdilution method recommended by the Clinical and Laboratory Standards Institute was used to determine the minimum inhibitory concentration (MIC) $[25,26]$. Antibacterial activity test was performed in Mueller-Hinton broth and for antifungal test RPMI-1640 medium with L-glutamine, buffered with MOPS buffer was used. The inoculum densities were approximately $5 \times 10^{5} \mathrm{CFU} / \mathrm{mL}$ and $0.5-2.5 \times 10^{3} \mathrm{CFU} / \mathrm{mL}$ for bacteria and fungi, respectively. Each essential oil was dissolved in Tween 80 and sterile distilled water. Final two fold concentrations were prepared in the wells of the microtiter plates, between 2,000-10 $\mu \mathrm{g} / \mathrm{mL}$. Chloramphenicol and nystatin were used as reference antibiotics for bacteria and fungi, respectively $(64-0.0625 \mu \mathrm{g} / \mathrm{mL})$. Microtiter plates were incubated at $35 \pm 2{ }^{\circ} \mathrm{C}$ for $18-24 \mathrm{~h}$ for bacteria and at $22{ }^{\circ} \mathrm{C}$ for $48 \mathrm{~h}$ for yeast. After the incubation period, MIC values were defined as the lowest concentration of the oils that inhibits the visible growth of microorganisms. 


\subsection{Brine Shrimp Lethality Bioassay}

The artificial seawater used in the experiments presented the following composition: $\mathrm{NaCl} 24 \mathrm{~g} / \mathrm{L}$, $\mathrm{CaCl}_{2} \cdot 2 \mathrm{H}_{2} \mathrm{O} 1.5 \mathrm{~g} / \mathrm{L}, \mathrm{KBr} 0.1 \mathrm{~g} / \mathrm{L}, \mathrm{KCl} 0.7 \mathrm{~g} / \mathrm{L}, \mathrm{Na}_{2} \mathrm{SO}_{4} 4.0 \mathrm{~g} / \mathrm{L}, \mathrm{NaHCO}_{3} 0.3 \mathrm{~g} / \mathrm{L}, \mathrm{MgCl}_{2} \cdot 6 \mathrm{H}_{2} \mathrm{O} 11 \mathrm{~g} / \mathrm{L}$. The essential oils were dissolved in tween 80 and DMSO (1:1) followed by artificial seawater. Ten shrimps (Artemia salina Leach) were transferred into test tubes in quadruplicate, containing the following essential oil concentrations: $10,50,100,500$ and $1,000 \mu \mathrm{g} / \mathrm{mL}$. The tubes were maintained under illumination. Survivors were counted $24 \mathrm{~h}$ after exhibition to the oil. Thymol was used as standard [21]. $\mathrm{CL}_{50}$ 's and 95\% confidence intervals were from the 24-hour counts using the probit analysis method [27].

\section{Conclusions}

Based on our results we can conclude that $\beta$-elemene, caryophyllene oxide and $\beta$-selinene were the main constituents of the essential oils from Duguetia lanceolata. Both oils (T2 and T4) demonstrated antimicrobial activity against Staphylococcus aureus, Streptococcus pyogenes and Candida albicans reference strains tested and were poisonous against Artemia salina. However, even a small variation in the total chemical composition of essential oils may contribute for different levels of biological activities expression.

\section{Acknowledgments}

We are grateful to FAPEMIG, CAPES and CNPq. We are also indebted to Fátima Regina Salimena Pires, from the Universidade Federal de Juiz de Fora (Juiz de Fora, Minas Gerais, Brazil), for plant identification.

\section{References}

1. Reichling, J.; Schnitzler, P.; Suschke, U.; Saller, R. Essential oils of aromatic plants with antibacterial, antifungal, antiviral, and cytotoxic properties-An overview. Forsch. Komplementmed. 2009, 16, 79-90.

2. Upadhyay, R.K.; Dwivedi, P.; Ahmad, S. Screening of antibacterial activity of six plant essential oils against pathogenic bacterial strains. Asian J. Med. Sci. 2010, 2, 152-158.

3. Cheng, A.-X.; Lou, Y.-G.; Mao, Y.-B.; Lu, S.; Wang, L.-J.; Chen, X.-Y. Plant terpenoids: Biosynthesis and ecological functions. J. Integr. Plant Biol. 2007, 49, 179-186.

4. Pérez, E.G.; Cassels, B.K. Alkaloids from the genus Duguetia. In The Alkaloids: Chemistry and Biology; Cordell, G.A., Ed.; Academic Press (Elsevier): London, UK, 2010; pp. 83-156.

5. Leboeuf, M.; Cave, A.; Bhaumik, P.K.; Mukherjee, B.; Mukherjee, R. The phytochemistry of the Annonaceae. Phytochemistry 1982, 21, 2783-2813.

6. Maia, J.G.S.; Andrade, E.H.A.; Carreira, L.M.M.; Oliveira, J. Essential oil composition from Duguetia species (Annonaceae). J. Essent. Oil Res. 2006, 18, 60-63. 
7. Almeida, J.R.G.; Facanali, R.; Vieira, M.A.R.; Marques, M.O.M.; Lúcio, A.S.S.C.; Lima, E.O.; Agra, M.F.; Barbosa-Filho, J.M. Composition and antimicrobial activity of the leaf essential oils of Duguetia gardneriana Mart. and Duguetia moricandiana Mart. (Annonaceae). J. Essent. Oil Res. 2010, 22, 275-278.

8. Siqueira, J.M.; Ziminiani, M.G.; Resende, U.M.; Boaventura, M.A.D. Activity-guided isolation of the constituents from bark of stem of Duguetia glabriuscula-Annonaceae, using brine shrimp lethality test (BSL). Quim. Nova 2001, 24, 185-187.

9. Sousa, O.V.; Soares Júnior, D.T.; Del-Vechio, G.; Mattosinhos, R.G.; Gattass, C.R.; Kaplan, M.A.C. Atividades antinociceptiva e antiinflamatória do óleo essencial de cascas de Duguetia lanceolata St. Hil., Annonaceae. Rev. Bras. Farmacogn. 2004, 14, 11-14.

10. Sousa, O.V.; Del-Vechio-Vieira, G.; Amaral, M.P.H.; Pinho, J.J.R.G.; Yamamoto, C.H.; Alves, M.A. Efeitos antinociceptivo e antiinflamatório do extrato etanólico das folhas de Duguetia lanceolata St.-Hil. (Annonaceae). Lat. Am. J. Pharm. 2008, 27, 398-402.

11. Fischer, D.C.H.; Gualda, N.C.A.; Bachiega, D.; Carvalho, C.S.; Lupo, F.N.; Bonotto, S.V.; Alves, M.O.; Yogi, Á.; di Santi, S.M.; Avila, P.E.; et al. In vitro screening for antiplasmodial activity of isoquinoline alkaloids from Brazilian plant species. Acta Trop. 2004, 92, 261-266.

12. Mallavarapu, G.R.; Rao, B.R.R.; Kaul, P.N.; Ramesh, S. Contribution of the essential oils of leaf, petiole and stem of scented geranium to the odour of geranium oil. J. Med. Aromat. Plant Sci. 1997, 19, 1020-1023.

13. Rao, B.R.R.; Sastry, K.P.; Saleem, S.M.; Rao, E.V.S.P.; Syamasundar, K.V.; Ramesh, S. Volatile flower oils of three genotypes of rose-scented geranium (Pelargonium species). Flavour Fragr. J. 2000, 15, 105-107.

14. Jürgens, A.; Webber, A.C.; Gottsberger, G. Floral scent compounds of Amazonian Annonaceae species pollinated by small beetles and thrips. Phytochemistry 2000, 55, 551-558.

15. Chalchat, J.C.; Garry, R.P.; Menut, C.; Lamaty, G.; Malhuret, R.; Chopineau, J. Correlation between chemical composition and antimicrobial activity. VI. Activity of some African essential oils. J. Essent. Oil Res. 1997, 9, 67-75.

16. Senatore, F.; de Fusco, R.; Napolitano, F. Eupatorium cannabinum L ssp. cannabinum (Asteraceae) essential oil: Chemical composition and antibacterial activity. J. Essent. Oil Res. 2001, 13, 463-466.

17. Essien, E.E.; Ogunwande, I.A.; Setzer, W.N.; Ekundayo, O. Chemical composition, antimicrobial, and cytotoxicity studies on S. erianthum and S. macranthum essential oils. Pharm. Biol. 2012, 50, 474-480.

18. Yang, D.; Michel, L.; Chaumont, J.P.; Millet-Clerc, J. Use of caryophyllene oxide as an antifungal agent in an in vitro experimental model of onychomycosis. Mycopathologia 1999, 148, 79-82.

19. Costa, T.R.; Fernandes, O.F.; Santos, S.C.; Oliveira, C.M.; Lião, L.M.; Ferri, P.H.; Paula, J.R.; Ferreira, H.D.; Sales, B.H.; Silva, M.R. Antifungal activity of volatile constituents of Eugenia dysenterica leaf oil. J. Ethnopharmacol. 2000, 72, 111-117. 
20. Cimanga, K.; Kambu, K.; Tona, L.; Apers, S.; de Bruyne, T.; Hermans, N.; Totté, J.; Piters, L.; Vlietinck, A.J. Correlation between chemical composition and antibacterial activity of essential oil of some aromatic medicinal plants growing in the Democratic Republic of Congo. J. Ethnopharmacol. 2002, 79, 213-220.

21. Meyer, B.N.; Ferrigni, N.R.; Putnam, J.E.; Jacobsen, L.B.; Nichols, D.E.; McLaughlin, J.L. Brine shrimp: A convenient general bioassay for active constituents. Planta Med. 1982, 45, 31-34.

22. Adams, R.P. Identification of Essential Oil Components by Gas Chromatography/Mass Spectrometry, 4th ed.; Allured Publishing Co.: Carol Stream, IL, USA, 2007.

23. Van den Dool, H.; Kartz, P.D. A generalization of the retention index system including linear temperature programmed gas-liquid partition chromatography. J. Chromatogr. A 1963, 11, 463-471.

24. Rios, J.L.; Recio, M.C.; Villar, A. Screening methods for natural products with antimicrobial activity: A review of the literature. J. Ethnopharmacol. 1988, 23, 127-149.

25. Clinical and Laboratory Standards Institute. Methods for Dilution Antimicrobial Susceptibility Tests for Bacteria That Grow Aerobically: Approved Standard, 8th ed.; M07-A8; Clinical and Laboratory Standards Institute: Wayne, PA, USA, 2008.

26. Clinical and Laboratory Standards Institute. Reference Method for Broth Dilution Antifungal Susceptibility Testing of Yeasts: Approved Standard, 3rd ed.; M27-A3; Clinical and Laboratory Standards Institute: Wayne, PA, USA, 2008.

27. Litchfield, J.T.; Wilcoxon, F. A simplified method of evaluating dose-effect experiments. J. Pharmacol. Exp. Ther. 1946, 96, 99-113.

Sample Availability: Samples of the essential oils from Duguetia lanceolata St. Hil. barks are available from the authors.

(C) 2012 by the authors; licensee MDPI, Basel, Switzerland. This article is an open access article distributed under the terms and conditions of the Creative Commons Attribution license (http://creativecommons.org/licenses/by/3.0/). 